\title{
SHE IS A WOMAN, SHE IS PREGNANT... SHE IS THE MINISTER OF DEFENSE. A COMPARATIVE ANALYSIS OF THE MEDIA REPRESENTATION OF THE FIRST FEMALE DEFENSE MINISTER IN SPANISH HISTORY ${ }^{1}$
}

\author{
AUTHOR: FERNÁNDEZ GARCÍA, Nuria \\ Researcher - Gabinete de Comunicación y Educación, Departamento de Periodismo y Ciencias de la Comuni- \\ cación, Universitat Autònoma de Barcelona (UAB) - Spain
}

nurfergar@gmail.com

\begin{abstract}
Studies examining newspaper coverage of politics have found female politicians to be disadvantaged as compared with their male counterparts, as women tend to attract lower overall attention and to receive less substantive coverage than men. Yet little systematic analysis has been devoted to the coverage of ministers of the same portfolio in different government cabinets. This paper explores the media treatment of three Spanish Defense ministers: the first female Spanish Defense minister, Carme Chacón, the former minister of Defense, José Bono (also a member of the Socialist government), and her successor, Pedro Morenés (from the Conservative People's Party). Based on a sample of news articles from the four main Spanish newspapers, I analyze the first days of the coverage of the three Defense ministers. The analysis compares the cove-
\end{abstract}

rage appointment in quantitative and qualitative terms, focusing on 1) the visibility and prominence of their appointments; 2) number of statements by the ministers represented in the news; 3) mentions of politicians appearance and private life, as well as mentions of their professional background; 4) mentions of the gender of the ministers; 5) traits associated to the ministers (positive and negative traits); and 6) the overall slant of the coverage. The study presents new evidence on the differential treatment by the media of women politicians assigned to high-prestige and powerful positions.

\section{Key words}

gender, stereotypes, ministers, print media, Spain.

\section{Introduction}

In 2007, Spain enacted the so-called Law of Equality (Organic Law 3/2007, March 22 ${ }^{\text {nd }}$, for Effective Equality between Women and Men). One provision of the bill says women must make up at least 40 percent of the lists of candidates that parties field in elections, with the aim of ensuring women's presence in the political sphere. But before the entry into force of the law, after the Spring 2004

\footnotetext{
${ }^{1}$ I would like to thank Professor Diana B. Carlin from Saint Louis University (SLU) for her helpful comments and for her pioneering work on the representation of women politicians in the media. An incomplete version of this paper was presented at the National Communication Association Conference (November 1518, 2012, Orlando, Florida).
}

election, Socialist Prime Minister José Luis Rodríguez Zapatero formed the first Spanish Government to have the same number of female as male cabinet ministers (eight of each). In his second-term (2008 - 2011), Rodríguez Zapatero formed a cabinet with more women than men (nine women to eight men).

This increase in the access of women to political office should arguably result in a normalization of the representation of women politicians in the press coverage. If women and men have comparable access to positions of power, if women access to the highest offices, should not this mean the disappearance of existing stereotyping gender roles? Unfortunately, different studies point out that while 
entrance of female politicians into the political sphere is increasing, gender biases disseminated by the media are still significant (Falk 2008; Fernandez 2010; Kittilson \& Fridkin 2008). Because the media have become the public sphere in which the identity of the politician is constructed, those gender biases can have electoral consequences. Thus, gender differences in media coverage may influence women's participation in public life, voters' evaluations of male and female candidates, candidates' choice of campaign strategies, and people's view regarding women's role in the political scene (Falk 2008; Kittilson \& Fridkin 2008; Norris 1997).

Although some disparities exist between the different studies analyzing the relationship between gender and the news coverage a politician receives, there is a significant amount of research that suggests that the press covers men and women politicians differently. Some studies suggest that women receive lower, less prominent and less substantive coverage than do men (Aday \& Devitt 2001; Braden 1996; Heldman, Carroll, \& Olson 2000; Kahn 1992, 1994, 1996; Kahn \& Goldenberg 1991); women's viability as election contenders is often framed more negatively than men's (Falk 2008; Fernandez 2010; Kahn 1994, 1996; Lawrence \& Ross 2010); gender of women politicians is more likely to be highlighted by the media (Anderson 2007; Bystrom, Robertson \& Banwart 2001; Falk 2008; Gidengil \& Everitt 1999; Heldman, Carroll \& Olson 2000, 2005; Norris 1997; Ross 2002; Sreberny-Mohammadi \& Ross 1996; Valenzuela \& Correa 2006); news reports on women leaders tend to focus on personal appearance rather than on policy issues (Braden 1996; Norris 1997; Ross 2000; Witt, Paget \& Mattews 1994); media refer to women more informally than men (Uscinski \& Goren 2011); women are more likely to have their titles (such as Senator or Representative) dropped in news stories, and they are more often referred to by their first names or as 'Ms.' or 'Mrs.' than are men to have their 'Mr.' substituted for their titles (Falk 2008); women politicians are also more likely to be described in terms of the personal traits associated with traditional 'female' stereotypes (Kahn 1994); the press discusses "female" issues more frequently when covering women politicians and reports "male" issues more extensively with men politicians (Kahn 1991, 1994; Kahn \& Goldenberg 1991); news coverage is more likely to emphasize women politicians' relationships to powerful or influential men (Baider 2007); media tend to use more highly charged language to report the speeches of female politicians (Gidengil \& Everitt 2003), and quotes of women politicians are more rarely represented in the media (Fernandez 2010).

Research also suggests that gender differences in news coverage may have become less pronounced in recent years (Bystrom, Robertson \& Banwart 2001; Jalalzai 2006). One reason may be the increase of women in elective positions. Van Acker (2003) suggests that when the number of women increases, particularly in the higher ranks, they will generate "less curiosity for the media" (:132), and it will translate into more gender-neutral coverage. Thus, with greater women representation in high-prestige positions, is press coverage becoming more genderneutral?

Women political participation in Spain has increased substantially in the last 30 years. In relation to the executive office, in 1936, during the Second Spanish Republic, Federica Montseny became the first woman to hold a ministerial office in Spain and one of the first in Europe. After the Franco dictatorship (1939 - 1975) and the restoration of Spanish democracy, the government of Leopoldo Calvo Sotelo (Union of the Democratic Centre, UCD) appointed Soledad Becerril Minister of Culture in 1981. It was not until 1988 that a woman would access to a ministerial position again. It was during the second government of the Spanish Socialist Workers' Party (PSOE) when Matilde Fernandez (Social Affairs) and Rosa Conde (Speaker of the Government) became ministers. The presence of women in subsequent socialist governments varied from 11 percent (1989 - 1993) to 16 percent (1993-1996). The figure rose to 26 percent with the first cabinet formed by the conservative People's Party (PP) (1996-2000), but dropped to 16 percent in the next term (2000-2004). The Socialist victory in the 2004 general election led to the first gender- 
balanced government in Spain's history, as exactly eight out of the sixteen members of the government were women, although men continued to occupy positions in defense, foreign affairs, economic affairs, justice, interior and industry, and women were allocated health affairs, as well as education, culture, agriculture, and environment. In his second-term (2008 - 2011), Prime Minister Rodríguez Zapatero formed a cabinet integrated by nine women and eight men. In this new cabinet women were appointed to positions in areas that had traditionally been restricted to men, such as defense, foreign affairs and economy. This government had the appointment of Carme Chacón as a Defense minister. Chacón, age 37, former Housing minister in the first Socialist government, was 7 months pregnant in the moment of her appointed. Photos of Chacón reviewing the soldiers while seven months pregnant and wearing white maternity blouse ran on the front pages of newspapers around the world. Following the general elections held in November 2011, Mariano Rajoy, from the conservative People's Party, was elected Prime Minister. He appointed a cabinet composed by only four women out of thirteen members. After some replacements in the Cabinet the proportion of women is the same: four out of thirteen members.

The present research explores the media treatment of Carme Chacón's appointment in 2008. I compare Chacón's appointment with the former minister of Defense, José Bono (also a member of the Socialist government), and her successor, Pedro Morenés (from the Conservative People's Party). Specifically, did the press represent Chacón in a different way to their male colleagues? In order to answer this question, I content-analyze the coverage of the three Defense ministers. Findings will be compared to see how the media coverage differs depending on politicians' gender, and the type of newspaper analyzed (conservative or liberal media).

\section{Methodology}

This study examines news coverage of the appointment of Carme Chacón, the first female Minister of Defense in Spain during the second term government of Socialist José Luis Rodríguez Zapatero (2008-2011). I compare her appointment with the first Defense Minister of Socialist government, José Bono (2004-2006), and her immediate successor, Pedro Morenés (2011 - ), from the Conservative People's Party.

I analyze Chacón's appointment because she holds a high-prestige, traditionally masculine, and powerful ministry, and this position is highly visible and has significant control over policy (Krook \& O'Brien 2011). As some differences in the representation of women may be due to their assignment to lowprestige portfolios (see Escobar-Lemmon \& TaylorRobinson 2005, 2009), Chacón's appointment to the Defense portfolio gives the opportunity to analyze and compare how the media frames a woman holding a powerful position.

Data were collected from four Spanish newspapers, El País (center-left), La Vanguardia (center-right), El
Mundo (right-wing) and $A B C$ (conservative). Those newspapers were selected for this study because of their ideological differences and because they are the four newspapers with the largest circulations in Spain (see Reig 1998). Thus, they have the greatest potential to impact audiences in terms of their agenda-setting influence on the rest of the Spanish media (Kahn \& Goldenberg 1991; Shoemaker \& Reese 1996).

The time frame chosen for the sample is the day before and the fifth days after the ministers are appointed. As Norris (1997) observes this frame coverage "may be particularly important since it helps shape initial perceptions of a leader's character, experience, and background for readers with little prior background information" (:157). Thus, this time period provides sufficient time to analyze how initial coverage of the three Defense ministers appointments, as well as the responses to them, unfolded in news media.

The unit of analysis of this study consists of the news article. The analysis examines not only news stories (traditionally thought as 'neutral' news pieces), but 
also editorials and opinion columns, because they are also included in the journalistic performance. Articles were searched for and retrieved from the Lexis Nexis and Factiva news database using a guide news search. The search terms used were the names of the Defense ministers. Once all articles had been compiled, they were compared to eliminate any duplication or the articles that would mention the name of the Ministers only in passing with the main focus of the story having nothing to do with them. These stories were not used in the final analysis. The total number of articles included in the sample is 215 articles ${ }^{1}$.

The coding follows previous research on differences in the media coverage of men and women politicians (see Aday and Devitt 2001; Falk 2008;
Heldman, Carroll \& Olson 2005; Kahn 1996; Kittilson \& Fridkin 2008; Miller, Peake \& Boulton 2009; Scharrer 2002; Trimble 2007). The categories developed include variables encompassing demographic and general data (e.g., politician name, gender, publication, publication date, section, page number) as well as a set of categories designed to identify characteristics and the representation of each politician. These categories include visibility (amount of coverage); mentions of politician's marital status, age, family, appearance, professional experience; mentions of politician gender; number of statements by the politicians represented in the news; traits associated with the male and female politicians (positive and negative traits); and the overall slant of the coverage (positive, neutral, mix, negative tone).

\section{Women, Media and Politics}

A number of studies have found that male politicians usually receive more press attention than women (Kahn 1992, 1994, 1996; Kahn \& Goldenberg 1991; Norris 1997; Ross 2002; Scharrer 2002; Serini, Powers \& Johnson 1998). For example, Norris (1997) found that female Prime Ministers and Presidents received a smaller amount of press coverage in the week after their election than did equivalent male leaders. However, more recent works have showed that, as women have attained higher levels of representation over time, the amount of coverage has balanced (Atkeson \& Krebs 2007; Kittilson \& Fridkin 2008) or even reversed to women's advantage (Banwart, Bystrom \& Robertson 2003; Bystrom, Robertson \& Banwart 2001; Trimble 2007). In the present study, visibility is measured in two ways. I code the number of articles that mention a politician in the story and the number of headlines that named the Minister.

Quantity is important because if women receive less coverage they may enjoy less name recognition (Jalalzai 2006; Kahn \& Goldenberg 1991), and the politicians who have less coverage are less likely to be recognized and be supported by the polls (Kahn 1996). But even if women do not receive less coverage than men, quality of coverage may differ. Different researches have found that women politicians are more likely to be identified in spousal or parental roles than men (Anderson 2007; Banwart, Bystrom \& Robertson 2003; Carlin \& Winfrey 2009; Falk 2008; Fernandez 2010), the press coverage is more likely to focus on how women look and what they wear so than do reports of men politicians (Aday \& Devitt 2001; Braden 1996; Bystrom, Robertson \& Banwart 2001; Carlin \& Winfrey 2009; Falk 2008; Fernandez 2008, 2010), and media are more likely to focus on the age of a woman politician than a male politician (Devitt 2002). Therefore, mentions of the marital status, age, family, and appearance of each individual minister are coded. Falk (2008) also suggests that women are more likely to have their professional background dropped in news stories, so they are shown with less experience (see also Fernandez 2010). Thus, mentions of the politician's professional experience are also noted.

Other categories analyzed are the mentions of the gender of the politicians. Different studies show that the gender of women politicians is more likely mentioned than male candidate's gender (Anderson 2007; Bystrom, Robertson and Banwart 2001; Falk 2008; Fernandez 2010; Gidengil \& Everitt 1999; Heldman, Carroll \& Olson 2000, 2005; Norris 1997; Ross 2002; Sreberny-Mohammadi \& Ross 
1996; Valenzuela \& Correa 2006). As Falk (2008) points out, this mention of women politicians' gender may reinforce the idea that "women are acting in an unnatural sphere or that men are more appropriate in these positions (...) and emphasizes that sex is important and relevant to politics" (: 94). In order to test this proposition, all mentions of the gender of a politician are coded.

Actual personalization of politics emphasizes the personality of politicians gaining more importance the traits related to personal qualities (see van Zoonen 1998). Earlier studies defined traits as stereotypically masculine or feminine (traits associated with leadership would be stereotypically masculine and traits associated with expressive personality traits would be stereotypically feminine) (see Carroll \& Fox 2006; Kahn 1994, 1996; Kittison \& Fridkin 2008) $)^{2}$. It is suggested that male traits dominate coverage of male candidates; whereas, these traits are discussed less often for female politicians. As 'male' traits are associated with 'leadership' traits, linked to stereotypically 'female' traits, "women politicians miss the opportunity to demonstrate their leadership, strength, and knowledge" (Kittilson \& Fridkin 2008: 386; see also Kahn \& Goldenberg 1991). Alternatively, later studies quantify and compare personal traits references with regard to their content, context and tone, classifying traits as 'positive' or 'negative' (see Miller, Peake \& Boulton 2009) ${ }^{3}$. Findings of studies using this methodology suggest that men are more likely to be associated with positive traits and women are more likely to be associated with negative traits (Fernandez 2010; Miller, Peake \& Boulton 2009). In the present study, a measure identifying mentions

\footnotetext{
${ }^{2}$ In this dichotomy, "male traits " include hardworking, strong leader, competitive, effective, tough, intelligent, aggressive, independent, ambitious; and "female traits" include gentle, weak, attractive, passive, dependent, emotional, unintelligent, compassionate, noncompetitive (see Atkeson \&Krebs 2007; Bem 1974; Dolan 2004; Kahn 1996; Kittilson \& Fridkin 2008).

${ }^{3}$ According to Miller, Peake \& Boulton (2009), traits are coded 'positive' or 'negative' based on their context in each article (i.e., a trait could be coded as positive in the context of one article and negative in the context of another).
}

of 'positive' or 'negative' traits is constructed in order to test for the hypothesis that women are more likely related to negative traits.

Another category to analyze is the number of statements made by male and female politicians represented in the news. According to Falk (2008), quotations are one vehicle by which the press can give voters direct information about politicians and politicians are eager to get direct access to citizens. Yet, there is some evidence that women politicians are less likely to be quoted by the media (Comas d'Argemir 2009; Lawrence \& Rose 2010; López Díez 2005). I code all direct quotations of men and women politicians to test if women are less likely to be quoted by the press.

Finally, the tone of the coverage is analyzed. Studies on gender stereotypes and female politicians have shown that, when a woman oversteps traditional boundaries the media react by covering her more negatively (Fernandez 2008, 2010; Kahn 1994; Kahn \& Goldenberg 1991; Lawrence \& Rose 2010; Scharrer 2002). In order to analyze the tone of coverage, I apply the methodology elaborated by Scharrer (2002) and used by Fernandez (2010) and Kittilson \& Fridkin (2009), classifying stories as positive, negative, mixed, or neutral to the Minister referred to ${ }^{4}$.

Based on previous literature and the elaborations above I test 10 central hypotheses that pertain to the amount, type and tone of Defense ministers' media coverage:

$\mathrm{H}_{1}$ : Female Defense minister received significantly less overall media coverage than male Defense ministers.

\footnotetext{
${ }^{4}$ In order to assess tone, this study has followed the methodology elaborated by Scharrer (2002) that determines that "the article is coded as 'positive' if there are clear words used to connote praise, approval, or any angle that portrayed the subject in a good light throughout. The article is rated as 'neutral' if there is no indication of either a positive or negative tone. The article is rated as 'mix' if there are isolated examples of negativity and positively. The article is rated as 'negative' if the politician is portrayed in a bad light throughout" (:405).
} 
$\mathrm{H}_{2}$ : Female Defense minister received significantly more media coverage that mentioned her dress/appearance than male Defense ministers.

$\mathrm{H}_{3}$ : Female Defense minister received significantly more coverage than mentioned her spousal or parental role than male Defense ministers.

$\mathrm{H}_{4}$ : Female Defense minister received significantly more mentions to her age than male Defense ministers.

$\mathrm{H}_{5}$ : Female Defense minister received significantly fewer mentions to her professional background than male Defense ministers.
$\mathrm{H}_{6}$ : Female Defense minister received significantly more coverage than mentioned her gender than male Defense ministers.

$\mathrm{H}_{7}$ : Female Defense minister received significantly more mentions to negative traits than male Defense ministers.

$\mathrm{H}_{8}$ : The media significantly less quoted female Defense minister than male Defense ministers.

$\mathrm{H}_{9}$ : Female Defense minister received significantly more negative coverage than male Defense ministers.

$\mathrm{H}_{10}$ : Female Defense minister received significantly more gendered coverage in the Conservative media than Liberal media.

\section{Results}

To examine the amount of coverage the content analysis counted the total number of stories mentioning each Defense Minister's name in each newspaper. In total, 215 stories were identified from the search. Breaking data by Minister, it is found that José Bono $(n=94)$ obtains a slightly higher coverage than Carme Chacón $(\mathrm{n}=92)$ and Pedro Morenés $(n=29)$. Table 1 shows that male ministers obtain more coverage from the conservative newspaper El Mundo, and Carme Chacón obtains more coverage from center-right newspaper La Vanguardia ${ }^{5}$. Therefore, $\mathrm{H}_{1}$ is rejected.

Table 1: Total Amount of Coverage (\%)

\begin{tabular}{|c|c|c|c|}
\hline & José Bono & Carme Chacón & Pedro Morenés \\
\hline EI Pais & $27.7(26)$ & $\begin{array}{l}14.1(13) \\
3.619\end{array}$ & $24.1(7)$ \\
\hline $\begin{array}{l}\text { La Vanguardia } \\
\text { EI Mundo }\end{array}$ & $\begin{array}{l}23.4(22) \\
30.9(29)\end{array}$ & $\begin{array}{l}31.5(29) \\
29.3(27)\end{array}$ & $\begin{array}{l}24.1(7) \\
27.6(8)\end{array}$ \\
\hline $\begin{array}{l}\begin{array}{l}A B C \\
\text { Total }\end{array} \\
\end{array}$ & $\begin{array}{l}18.1(17) \\
110(94)\end{array}$ & $\begin{array}{l}25.0(23) \\
100(92)\end{array}$ & $\begin{array}{l}24.1(7) \\
100(29)\end{array}$ \\
\hline
\end{tabular}

Note: Column percentages with number of mentions in parenthesis.

Context factors may explain these data. The high visibility of José Bono may be due to the fact that he has been a long known politician in the Spanish political scene and because given the international

\footnotetext{
${ }^{5}$ La Vanguardia, the fourth-highest circulation among Spanish general print media, has its headquarters in Catalonia. As Chacón is a Catalonian politician, this may be the cause of the high visibility of the female minister in the Catalonian based newspaper.
}

situation at April 2004 (the change in Iraq policy promised by the Socialist government), the Defense ministry actions were very important in the first days of the Socialist government. Instead Carme Chacón's high visibility in the news may be due to her presence on the male terrain of the Defense ministry. Novelty factor may explain her high visibility. Since Carme Chacón was the first female to be appointed Minister of Defense, it was expected that the media emphasized the novelty of having a female Defense minister by having a large amount of coverage (see Trimble 2007). Meanwhile, it is interesting point out the low amount of coverage of his successor, Pedro Morenés. Maybe this small attention to the conservative Defense minister may be due to the media interest to the appointment of the Spain's deputy prime minister most powerful woman (a mother of a baby born just one month before her appointment) and the appointment of the two economic ministries given the Spanish financial crisis situation,

Looking at mentions of Ministers in the articles headlines, Carme Chacón's visibility is very clear: 28.3 percent of stories mention her name in the headline. José Bono has 17 headlines that mention his name (18.1 percent of the stories about him), and Pedro Morenés is only mentioned twice in the headline (6.9 percent of articles about him). 
Visibility may be also examined by looking at the speech represented in the news. As shown in Table 2, male Defense ministers are more likely than the female Defense minister to have their speech represented in the news. José Bono is quoted in 28.7 percent of the stories about him; Pedro Morenés is quoted in 17.2 percent, whereas Carme Chacón is only quoted in 7.6 percent of the articles about her. This finding lead us to accept $\mathrm{H}_{8}$.

\begin{tabular}{|c|c|c|c|}
\hline \multicolumn{4}{|c|}{ Table 2: Quotations } \\
\hline & José Bono & Carme Chacón & Pedro Morenés \\
\hline Article Quotation & $28.7 \%(27)$ & $7.6 \%(7)^{* * *}$ & $17.2 \%(5)$ \\
\hline El País & $34.6 \%(9)$ & $7.7 \%(1)$ & $14.3 \%(1)$ \\
\hline La Vanguardia & $31.8 \%(7)$ & - & $28.6 \%(2)$ \\
\hline El Mundo & $31.0 \%(9)$ & $14.8 \%(4)$ & $12.5 \%(1)$ \\
\hline$A B C$ & $11.8 \%(2)$ & $8.7 \%(2)$ & $14.3 \%(1)$ \\
\hline
\end{tabular}

Note: Column percentages with base $\mathrm{n}$ in parenthesis. $* \mathrm{p}<.1 * * \mathrm{p}<.05 ; * * * \mathrm{p}<.01$

Almost all the newspapers analyzed spend more space representing men quotations than women quotations. Only right-wing newspaper El Mundo represents Chacón statements more often than statements made by the Conservative minister Morenés (14.8 vs $12.5 \%$ ).

Table 3 details the pattern in news representation of the personal life of the Ministers, summarizing mentions to marital status, age, family, appearance and professional experience ${ }^{6}$. Results show that Carme Chacón is more likely to have her marital status, age and appearance highlighted in the news about her, but in relation to family mentions differences by ministers are small. Consequently, it does seem that appearance, age and marital status are still an important descriptor in the media

\footnotetext{
${ }^{6}$ I code 'appearance', any reference to the minister's physical attributes or attire (included any reference to the pregnancy of the female minister). I code 'family', any reference to the minister's children, parents or other relatives. I code 'marital status', any reference to the minister's current or former spouse, or noting if he/she is single. I code 'age', any mention of the minister's age or generation. I code 'professional experience'; any description of the minister's professional training (see Devitt 1999: 41).
}

coverage of women Ministers. Given the results, we accept $\mathrm{H}_{2}, \mathrm{H}_{3}$ and $\mathrm{H}_{4}$.

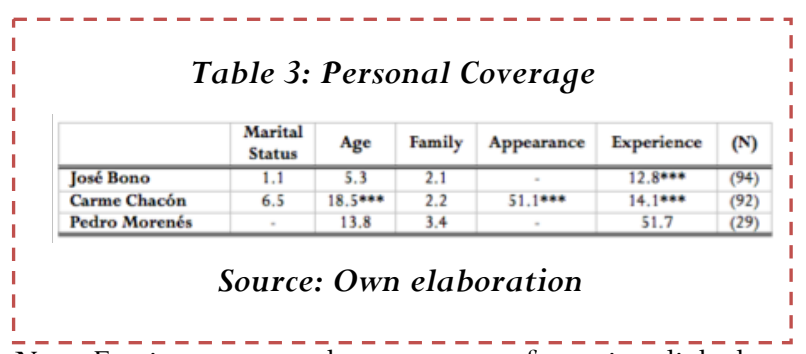

Note: Entries represent the percentage of mentions linked to a specific cabinet gender, based on the total number of stories mentioning each gender. ${ }^{*} \mathrm{p}<.1 ; * * \mathrm{p}<.05 ; * * * \mathrm{p}<.01$

By media, center-right newspaper La Vanguardia is more likely to mention Chacón's marital status (13.8\%), and El Mundo (25.9\%) devotes more mentions to Chacón's age. El Mundo also devotes more attention to her appearance: 6 out of 10 stories about Chacón mention her appearance (including references to her pregnancy) ${ }^{7}$. It must be highlighted that the most conservative newspaper, $A B C$, does not mention the marital status or the age of Chacón in any of its stories.

Table 3 also reports mentions of professional background, qualifications or experience of the cabinet members. Data reveal a higher percentage of mentions of the professional experience of the conservative minister (51.7 percent mentions in news about him). The situation is more balanced between the Socialist ministers: 14.1 percent of the stories about Chacón mentions her experience, and 12.8 percent of the stories about Bono. By media, right-wing newspaper El Mundo, the same newspaper that devotes the higher attention to her appearance, devotes the lowest attention to Chacón's experience (7.4\%), while it highlights Bono experience in 24.1 percent of the stories about him and Morenés' experience in 62.5 percent of the stories about him. Therefore, $\mathrm{H}_{5}$ is rejected.

As gender mentions are analyzed, the data show that newspapers are more likely to mention the gender of the female Defense minister (see Table 4). Chacón is rather often distinguished as 'woman' in

\footnotetext{
${ }^{7}$ A deeper study must be realized in order to evaluate the "pregnancy factor" in Chacón's media representation.
} 
press accounts (46.7 percent of the stories about her), while their male counterparts are hardly ever distinguished as being 'men'. Based on those results, we accept $\mathrm{H}_{6}$.

\begin{tabular}{|l|l|l|}
\hline \multicolumn{3}{|c|}{ Table 4: Mentions to Gender (\%) } \\
\hline \hline José Bono & Gender & $(\mathrm{N})$ \\
\hline \\
\hline
\end{tabular}

Note: Entries represent the percentage of mentions linked to a specific minister, based on the total number of stories mentioning each gender. ${ }^{*} \mathrm{p}<.1 ; * * \mathrm{p}<.05 ; * * * \mathrm{p}<.01$

All newspapers analyzed are more likely to mention Chacón's gender. There are some differences among the four newspapers analyzed. Center-right La Vanguardia mentions Chacón gender in 58.6 percent of the articles about her; whereas, the conservative $A B C$ devotes less attention to Chacón's gender (only 34.8 percent of the articles about the female minister mention her gender).

As can be seen from Table 5, Chacón's positive trait references were higher than Bono's but lower than Morenés', while her negative trait references were higher than male's. Coverage of Chacón's personality was positive on balance with 8.7 percent of her articles referencing positive traits (e.g., intelligent, hard worker) and 7.6 percent mentioning negative traits (e.g. inexpert, immature), for a net difference of 1.1. The net difference between positive and negative traits is always positive regardless of gender. Based on negative traits result, we accept $\mathrm{H}_{7}$.

Table 5: Positive and Negative Traits (\%)

\begin{tabular}{|l|c|c|c|c|}
\hline & $\begin{array}{c}\text { Positive } \\
\text { Traits }\end{array}$ & $\begin{array}{c}\text { Negative } \\
\text { Traits }\end{array}$ & $\begin{array}{c}\text { Net } \\
\text { Difference }\end{array}$ & (N) \\
\hline \hline José Bono & 4.3 & 4.3 & 0.0 & $(94)$ \\
\hline Carme Chacón & 8.7 & 7.6 & 1.1 & $(93)$ \\
\hline Pedro Morenés & 13.8 & - & 13.8 & $(29)$ \\
\hline \hline
\end{tabular}

Source: Own elaboration
Note: Entries represent the percentage of mentions linked to a specific cabinet gender, based on the total number of stories mentioning each gender. The $p$ value is based on the difference in percentages test. ${ }_{\mathrm{p}}<.1 ; * * \mathrm{p}<.05 ; * * * \mathrm{p}<.01$

The data show differences among the newspapers analyzed. Right-wing El Mundo and center-left El Pais are more likely to mention positive traits of Chacón (14.8\% and $15.4 \%$, respectively). In the case of El País the positive traits percentage is even higher than the positive traits percentage found for both male ministers. When negative traits are analyzed, El Mundo associates Chacón to negative traits in 14.8 percent of her stories; whereas, the other newspapers analyzed do so in 3.4 percent of the stories (La Vanguardia), 8.7 percent (ABC) of the pieces, or do not mention negative traits at all (El País). $A B C$ is unique in that it devotes more attention to Chacón negative traits $(8.7 \%)$ than to her positive traits $(4.3 \%)$.

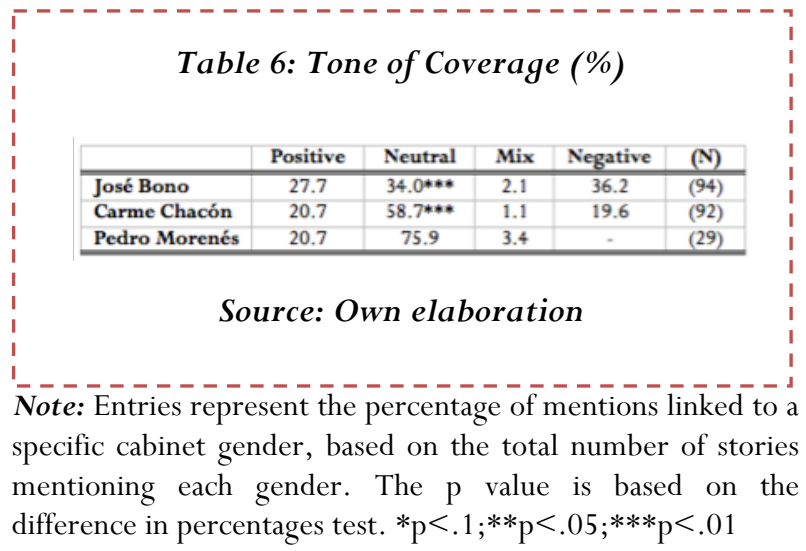

Finally, Table 6 reports the proportion of positive, neutral, mix and negative tone pieces received by men and women ministers. The findings show that Chacón is more likely to have a neutral tone (58.7 percent) than a positive $(20.7 \%)$ or a negative tone $(19.6 \%)$. Therefore, $\mathrm{H}_{9}$ is rejected.

By media, there are differences among the four newspapers analyzed. El País mainly associates all the ministers analyzed to a neutral tone. $L a$ Vanguardia and $A B C$ associate Conservative male minister and Socialist female minister to a neutral tone, and Socialist male minister to a negative tone, and negative tone is higher in El Mundo coverage of both Socialist ministers (37.9 percent of negative 
tone associated to Bono, and 37.0 percent of negative tone associated to Chacón).

\section{Conclusions}

This research suggests that stereotypes still affect the manner in which the media assess women politicians. In comparing newspaper coverage of three Defense ministers of the 2004, 2008 and 2011 Spanish cabinets, the analysis finds that coverage of female ministers show still some differences to men's despite the fact that the presence of women increased in 2004 to achieve for the first time a gender-balanced government, and the fact that in the 2008 cabinet of Rodríguez Zapatero women hold more cabinet positions and were allocated portfolios with higher levels of prestige as defense, foreign affairs or economy.

First, although Chacón, the first female Defense ministry in the history of Spain, get a high level of visibility in the news, she is noticeably less likely than her male colleagues to be quoted in the press. This data gives some indication as to the prevalence of men's politician discourse in the media and show that quotation amount is not related to the prestige of the Ministry. In the same high-prestige position, women's statements are less quoted. The press sends the message that Chacón is in the politics scene, but she has less to say than her male colleagues. Second, women's gender continues being a tag in the representation of a woman in the media. Chacón's gender is considered much more relevant, important, and worth reporting than her male colleagues' gender. Thus, the subtle message is that women still are political outsiders. Third, it does seem that women's appearance, age, and marital status are still important in the media coverage of female ministers. Results also confirm that women politicians receive more negative traits coverage than men. Chacón is related to positive traits (even more than her Socialist colleague) but it is also true that she is more likely to receive negative trait references in a higher percentage than both male ministers. On the other hand, the tone of the three ministers in reporting news is mainly neutral, although both Socialist Defense ministers receive more negative tone coverage than their Conservative counterpart.

In sum, this preliminary interpretation suggests that media still perpetuates gender stereotypes that portray women in terms of long-standing gender stereotypes. And the differences go beyond the ideology of the media analyzed. Regardless of small differences, Liberal and Conservative newspapers show a bias when they represent women politicians.

But is it because women are still a novelty in heavily masculinized positions? To answer this question future research should be realized, it should explore more subtle forms of gendered coverage (e.g., verbs used by the media to report politicians speech), and it should include a wider variety of media outlets (e.g., television news, weblogs). Research should also look at the media coverage in a comparative perspective to know if a more presence of women in high-prestige positions means greater balance in the representation of women and men in the news.

\section{References}

- Aday, S. \& Devitt, J. (2001). Style Over Substance: Newspaper Coverage of Elizabeth Dole's Presidential Bid. Harvard International Journal of Press/Politics, 6 (2), 61-73.

- Anderson, L. (2007). Gendered and Racialized Portrayals of the Governor General: Newspaper Coverage of Canada's
Head of State, paper presented at the Annual Meeting of the Canadian Political Science Association, Saskatoon, May 30 - June 1, 2007.

- Atkeson, L.R. \& Krebs, T.B. (2007). Press Coverage of Mayoral Candidates: The Role of Gender in News Reporting and Campaign 
Issue Speech. , Political Research Quarterly, 61(2): $239-252$.

- Baider, F. (2007). Feminisation in Linguistics, Women in Politics: How is the French Press Coping?. International Perspectives on Gender and Language: Cuaderno da langage e sexo, 3, $770-794$.

- Banwart, M.C., Bystrom, D.G. \& Robertson, T. (2003). From the Primary to the General Election: A Comparative Analysis of Candidate Media Coverage in Mixed-Gender 2000 Races for Governor and U.S. Senate. American Behavioral Scientist, 46, $658-674$.

- Bem, S. (1974). The Measurement of psychological androgyny. Journal of Consulting and Clinical Psychology, 42, 155-162.

- Braden, M. (1996). Women Politicians and the Media. Lexington, Kentucky: The University Press of Kentucky.

- Bystrom, D.G., Robertson, T. \& Banwart, M.C. (2001). Framing the Fight: An Analysis of Media Coverage of Female and Male Candidates in Primary Races for Governor and Senate in 2000. American Behavioral Scientist, 44 (12), 1999-2013.

- Carlin, D.B. \& Winfrey, K.L. (2009). Have You Come a Long Way, Baby? Hillary Clinton, Sarah Palin, and Sexism in 2008 Campaign Coverage. Communication Studies, $60(4), 326-343$

- Carroll, S.J. \& Fox, R. (2006). Gender and Elections: Shaping the Future of American Politics. Cambridge: Cambridge University Press.

- Comas d'Argemir, D. (2009). Les dones en els informatius de televisió. Quaderns del CAC, 33, $97-108$.

- Devitt, J. (2002). Framing gender on the campaign trail: female gubernatorial candidates and the press. Journalism and Mass Communication Quarterly, 79 (2), 445 - 463.
- Dolan, K. (2004). Voting for Women: How the Public Evaluates Women Candidates. Boulder, Colorado: Westview Press.

- Escobar-Lemmon, M. \& Taylor-Robinson, M.M. (2005). Women Ministers in Latin American Government. American Journal of Political Science, 49 (4), 829-844.

- Escobar-Lemmon, M. \& Taylor-Robinson, M.M. (2009). Getting to the Top: Career Paths of Women in Latin American Cabinets. Political Research Quarterly, 62 (4), 685-699.

- Falk, E. (2008). Women for President: Media bias in eight campaigns. Chicago, IL: University of Illinois Press.

- Fernandez García, N. (2008). La construcción mediática del líder política desde una perspectiva de género: Análisis del tratamiento de Ségolène Royal en las columnas de opinion de Le Figaro y Libération durante las elecciones primarias del Partido Socialista Francés. In R. PérezAmat, S. Núñez, and A. García (coord.), Comunicación, identidad y género. Madrid: Editorial Fragua.

- Fernandez Garcia, N. (2010). Framing Hillary Clinton en la Prensa Española: ¿Candidata o Mujer?. Observatorio (OBS*) Journal, 4 (3), $209-228$.

- Gidengil, E. \& Everitt, J. (1999). Metaphors and misrepresentation: Gendered mediation in news coverage of the 1993 Canadian leaders' debates. Press / Politics, 4 (1), 48 65.

- Gidengil, E. \& Everitt, J. (2003). Tough Talk: How Television News Covers Male and Female Leaders of Canadian Political Parties”, in M. Tremblay and L.Trimble (ed.), Women and Electoral Politics in Canada. Toronto: Oxford University Press.

- Heldman, C., Carroll, S.J. \& Olson, S. (2000). Gender differences in print media 
coverage of presidential candidates: Elizabeth Dole's bid for the Republican nomination. Paper presented to the Annual Conference of the American Political Science Association, Washington D.C., September 2000.

- Heldman, C., Carroll, S.J. \& Olson, S. (2005). She brought only a skirt: Print media coverage of Elizabeth Dole's bid for the Republican presidential nomination. Political Communication, 22 (3), $315-335$.

- Jalalzai, F. (2006). Women Candidates and the Media: 1992-2000 Elections. Politics \& Policy, 34 (3), 606-633.

- Kahn, K. F. (1991). Gender differences in campaign messages: The political advertisements of men and women candidates for U.S. Senate. Political Research Quarterly, $46,481-502$.

- Kahn, K.F. (1992). Does being a male help? An investigation of the effects of candidate gender and campaign coverage on evaluations of US Senate candidates?. Journal of Politics, 54 (2), 497-517.

- Kahn, K.F. (1994). Does Gender Make a Difference? An Experimental Examination of Sex Stereotypes and Press Patterns in Statewide Campaigns. American Journal of Political Science, 38 (1), 162-195.

- Kahn, K.F. (1996). The Political Consequences of Being a Woman. New York: Columbia University Press.

- Kahn, K.F. \& Goldenberg, E. (1991). Women Candidates in the News: An Examination of Gender Differences in U.S. Senate Campaigns. Public Opinion Quarterly, 55 (2), 180-199.

- Kittilson, M.C. \& Fridkin, K. (2008). Gender, Candidate Portrayals and Election Campaigns: A Comparative Perspective. Politics \& Gender, 4, 371-392.
- Krook, M.L. \& O’Brien, ,D. (2011). All the President's Men? The Appointment of Female Cabinet Ministers Worldwide. Paper presented at the Annual Conference of the Midwest Political Science Association, Chicago, IL, April 2011.

- Lawrence, R.G. \& Rose,, M. (2010). Hillary Clinton's Race for the White House. Gender Politics and the Media on the Campaign Trail. Boulder, CO: Lynne Rienner Publishers, Inc.

- López Díez, P. (2005). Representación de género en los informativos de radio y televisión. Madrid: Instituto Oficial de Radio y Televisión.

- Miller, M.K., Peake, J.S. \& Boulton, B. (2009). You've Come a Long Way Baby? Press Coverage of Hillary Clinton's Presidential Campaign. Paper presented at the annual conference of the Midwest Political Science Association, Chicago, IL, April 2009.

- Norris, P. (1997). Women Leaders Worldwide: A Splash of Color in the Photo Op. In P. Norris (ed.), Women, Media and Politics. Oxford: Oxford University Press.

- $\quad$ Reig, R. (1998). Medios de comunicación y poder en España. Barcelona: Paidós.

- Ross, K. (2000). Framed: Women, politics and news media in a general election climate. Coventry: Center for Communication, Culture and Media.

- Ross, K. (2002). Women, Politics, Media: Uneasy Relations in Comparative Perspective. Cresskill, NJ: Hampton Press.

- Scharrer, E. (2002). An 'Improbable Leap': a content analysis of newspaper coverage of Hillary Clinton's transition from first lady to Senate candidate. Journalism Studies, 3 (3), $393-406$.

- Semetko, H.A. \& Boomgaarden, H.G. (2007). Reporting Germany's 2005 Bundestang Election Campaign: Was Gender 
an Issue?. Press / Politics, 12 (4), 154 171.

- Serini, S.A., Powers, A.A. \& Johnson, S. (1998). Of Horse Race and Policy Issues: A Study of Gender in Coverage of a Gubernatorial Election by Two Major Metropolitan Newspapers. Journalism and Mass Communication Quarterly, 75 (1), 194 204.

- Shoemaker, P.J. \& Reese, S. (1996). Mediating the message: Theories of influences on mass media content. White Plains, NY: Longman.

- Sreberny-Mohammadi, A. \& Ross, K. (1996). Women MPs and the Media: Representing the Body Politic. Parliamentary Affairs, 49, 103 - 115.

- Trimble, L. (2007). Gender, political leadership and media visibility: Globe and Mail coverage of Conservative party of Canada leadership contests. Canadian Journal of Political Science, 40 (4), 969 - 993.

- Uscinski, J.E. \& Goren, L.J. (2011). What's in a Name? Coverage of Senator Hillary Clinton during the 2008 Democratic
Primary. Political Research Quarterly, 64 (4), $884-896$.

- Valenzuela, S. \& Correa, T. (2006). Madam or Mr. President? Chile's Michelle Bachelet Press Coverage and Public Perception. Paper presented at the Annual Convention of the Association for Education in Journalism and Mass Communication, San Francisco, CA, August 2006.

- $\quad$ van Acker, E. (2003). Media Representations of Women Politicians in Australia and New Zealand: High Expectations, Hostility and Stardom. Policy, Organization and Society, 22 (1), 116-136.

- Van Zoonen, L. (2004). Entertaining the Citizen: When Politics and Popular Culture Converge. Oxford: Rowman \& Littlefield Publishers.

- Witt, L., Paget, K.M. \& Matthews, G. (1995). Running as a Woman: Gender and Power in American Politics. New York, NY: The Free Press.

\section{Forma de Citación}

FERNÁNDEZ GARCÍA, Nuria: She is a woman, she is pregnant... she is the Minister of Defense. A comparative analysis of the media representation of the first female Defense minister in Spanish history. Revista Communication Papers, $N^{\circ} 7$, páginas 35 a 46. Departamento de Filología y Comunicación de la Universidad de Girona. Recuperado el__ de de 2 de: http://www.communicationpapers.es 